\title{
TABULAR ICEBERGS: IMPLICATIONS FROM GEOPHYSICAL STUDIES OF ICE SHELVES*
}

\author{
By Sion Shabtaie and Charles R. Bentley \\ (Geophysical and Polar Research Center, University of Wisconsin-Madison, Madison, \\ Wisconsin 53706, U.S.A.)
}

\begin{abstract}
Recent geophysical and glaciological investigations of the Ross Ice Shelf have revealed many complexities in the ice shelf that can be important factors in iceberg structure. The presence of rift zones, surface and bottom crevasses, corrugations, ridge/troughs, and other features could substantially modify the hydraulics of iceberg towing and lead to disintegration in the course of transport.

The relationships between the elevation above sea-level and total ice thickness for three ice shelves (Ross. Brunt, and McMurdo) are given; from them, expressions for the thickness/freeboard ratios of tabular icebergs calved from these ice shelves are obtained. The relationships obtained from the measured values of surface elevation and ice thickness are in agreement with models derived assuming hydrostatic equilibrium.

Areas of brine infiltration into the Ross Ice Shelf have been mapped. Examples of radar profiles in these zones are shown. Absorption from the brine layers results in a poor or absent bottom echo. It is probable that little saline ice exists at the bottom of the Ross Ice Shelf front due to a rapid bottom melting near the ice front, and that the thickness of the saline ice at the bottom of icebergs calving from the Ross Ice Shelf is no more than a few meters, if there is any at all.

We have observed many rift zones on the ice shelf by airborne radar techniques, and at one site the bottom and surface topographies of (buried) rift zones have been delineated. These rift zones play an obvious role in iceberg formation and may also affect the dynamics of iceberg transport. Bottom crevasses with different shapes, sizes, and spacings are abundant in ice shelves; probably some are filled with saline ice and others with unfrozen sea-water. Existence of these bottom crevasses could lead to a rapid disintegration of icebergs in the course of transport, as well as increasing the frictional drag at the ice-water boundary.

Radar profiles of the ice-shelf front at four sites in flow bands of very different characteristics are shown. In some places rifting up-stream from the front shows regular spacings, suggesting a periodic calving. Differential bottom melting near the front causes the icebergs to have an uneven surface and bottom (i.e. dome shaped).

Electrical resistivity soundings on the ice shelf can be applied to estimate the temperature-depth function, and from that the basal mass-balance rate. With some modifications, the technique may also be applied to estimating the basal mass-balance rates of tabular icebergs.
\end{abstract}

RÉSUMÉ. Icebergs tabulaires: implications tirées des études géophysiques des. De récentes recherches géophysiques et glaciologiques du Ross Ice Shelf ont révélé bien des complexitès de la calotte qui peuvent influer fortement sur la structure des icebergs. La présence de zones fissurées, de crevasses de surface ou de fond, de plissements, de crêtes et de sillons, et d'autres caractéristiques ont pu modifier substantiellement le comportement hydraulique de l'iceberg au remorquage et conduire à une désintégration pendant le cours du transport.

On donne les relations entre l'altitude au-dessus du niveau de la mer et l'épaisseur totale de la glace pour trois plateformes de glace (Ross, Brunt, et McMurdo); à partir de là on a obtenu des expressions pour le calcul de rapports épaisseur/hauteur émergée des icebergs tabulaires issus de ces plateformes. Les relations obtenues a partir des valeurs mesurées de l'altitude de la surface et de l'épaisseur de la glace concordent avec les modéles exprimant l'équilibre hydrostatique.

On a cartographié les zones d'infiltration d'eau salée dans le Ross Ice Shelf. On montre des exemples de profil radar dans ces zones. L'absorption par les niveaux de saumure se traduit par un écho de fond faible ou nul. Il est probable qu'un peu de glace saline existe au fond du front du Ross Ice Shelf á cause d'une fusion de fond rapide près du front de glace et que l'épaisseur de la glace saline, si elle existe, au fond des icebergs issus du Ross Ice Shelf n'est pas moindre que quelques mètres.

Nous avons observé beaucoup de zones fissurées sur la plateforme de glace par les techniques de radar aéroporté, et, sur un de ces sites la topographie du fond et de la surface des zones fissurées (enfouies) ont été délimitées. Ces zones fissurées jouent un rôle évident dans la formation des icebergs et peut aussi affecter la

* Geophysical and Polar Research Center, University of Wisconsin-Madison, Contribution No. 395. 
dynamique du transport des icebergs. Les crevasses de fond de différentes tailles, formes et espacements sont abondantes dans les plateformes de glace; quelques unes sont probablement remplies par de la glace saline et d'autres par de l'eau de mer non gelée. L'existence de ces crevasses de fond pourrait conduire á une rapide désintégration des icebergs dans le cours du transport, ainsi qu'à l'accroissement de la résistance de frottement à l'interface glace-eau.

On montre les profils radars de la falaise de la plateforme en quatre points sur des lignes de courant de caractéristique très différentes. En quelques points les fissures à l'amont de la falaise présentent des espacements réguliers suggérant l'hypothèse d'un vêlage régulier. Des fusions différentielles au fond près de la falaise explique que les icebergs ont une face inférieure inégale (c'est â dire en forme de dôme).

Les sondages de résistivité électrique sur la plateforme peuvent servir à estimer la fonction temperature/profondeur, et par là le bilan de masse au fond. Avec quelques modifications, la technique peut également servir à estimer le bilan de masse au fond des icebergs tabulaires.

Zusammenfassung. Tafeleisberge: Folgerungen aus geophysikalischen Studien von Schelfeisen. Neuere geophysikalische und glaziologische Untersuchungen am Ross Ice Shelf haben viele Verwicklungen im Schelfeis zu Tage gebracht, die für die Struktur von Eisbergen von Bedeutung sein können. Das Auftreten von Pressungszonen, Grund- und Oberflächenspalten, Verbiegungen, Rücken und Trögen sowie anderer Erscheinungen könnte die hydraulischen Verhältnisse beim Abschleppen eines Eisberges wesentlich verändern und zum Auseinanderbrechen im Laufe des Transportes führen.

Für drei Schelfeise (Ross, Brunt, und McMurdo) werden die Beziehungen zwischen der Höhe über dem Meeresspiegel und der gesamten Eisdicke angegeben; daraus lassen sich Ausdrücke für das Verhältnis Dicke zu Höhe über Wasser von Tafeleisbergen, die von diesen Schelfeisen kalbten, herleiten. Die Beziehungen, die aus den Messwerten der Oberflächenhöhe und der Eisdicke hergeleitet wurden, stimmen mit Modellen überein, die auf der Annahme eines hydrostatischen Gleichgewichts beruhen.

Die Gebiete mit Sole-Infiltration in das Ross Ice Shelf wurden kartiert. Beispiele für Radarprofile in diesen Zonen werden dargestellt. Die Absorption in Soleschichten führt zu einem schwachen oder fehlenden Echo an der Unterseite. Vermutlich gibt es an der Unterseite der Front des Ross Ice Shelf infolge der dort herrschenden schnellen Abschmelzung nur wenig salzhaltiges Eis; die Dicke salzhaltigen Eises am Untergrund von Eisbergen aus dem Ross Ice Shelf beträgt daher höchstens ein paar Meter,-wenn es dort überhaupt vorhanden ist.

Wir konnten mit Radarsondierungen aus der Luft viele Grabenzonen auf dem Schelfeis beobachten; an einer Stelle wurde die Topographie von verdeckten Grabenzonen an der Oberfläche und der Unterseite aufgezeichnet. Diese Zonen spielen offensichtlich bei der Bildung von Eisbergen eine Rolle und dürften auch die dynamischen Verhältnisse bei einem Eisbergtransport beeinflussen. Im Schelfeis gibt es zahllose Grundspalten mit verschiedenen Formen, Grössen und Abständen; teilweise sind sie vermutlich mit salzhaltigem Eis erfüllt, andere enthalten ungefrorenes Meerwasser. Das Vorhandensein dieser Grundspalten könnte zu einem raschen Zerfall von Eisbergen während des Transportes führen, ebenso aber zu einer Zunahme des Reibungswiderstandes an der Grenze von Eis und Wasser.

Von vier Stellen in Fliessbändern sehr verschiedener Art werden Radar-Profile der Schelfeis-Barriere wiedergegeben. An einigen Orten weisen die Graben eiseinwärts von der Barriere regelmässige Abstände auf, was auf periodische Kalbungen schliessen lässt. Unterschiedliche Abschmelzung am Untergrund in der Nähe der Barriere verursacht Unebenheiten auf der Oberfläche und am Untergrund der Eisberge (Gewölbeform).

Zur Abschätzung des Verlaufs der Temperatur mit der Tiefe und daraus der Massenbilanzrate am Untergrund können Sondierungen der elektrischen Leitfähigkeit herangezogen werden. Mit einigen Abänderungen lässt sich diese Technik auch zur Abschätzung der basalen Massenbilanzraten von Tafeleisbergen anwenden.

\section{INTRODUCTION}

During the years 1973-78 an extensive geophysical and glaciological survey was carried out over the Ross Ice Shelf. We present some of the results that can be useful in selecting tabular icebergs and that can lead to a better understanding of their physical characteristics. Virtually the same geophysical techniques as are used for ice-shelf studies can be used to study tabular icebergs, and of all the techniques radar sounding should have priority. 
Radar sounding was carried out both on the snow surface and on board a light aircraft (Twin Otter) using SPRI Mark II radar systems operating at 35 and $50 \mathrm{MHz}$. The instrumentation and recording techniques are discussed in Bentley and others (1979). Two echograms (Figs 9a and b) are from the data collected during the NSF-SPRI-TUD program of radar sounding on board a C-130 aircraft using the TUD $60 \mathrm{MHz}$ pulsed radar system.

\section{BUOYANCY AND THE RELATIONSHIP BETWEEN SURFACE AND BOTTOM TOPOGRAPHY}

On cold polar ice shelves such as the Ross Ice Shelf there is practically no melting on the surface; the rate of densification is principally controlled by the snow accumulation rate and the temperature in the ice. Since these processes change with time and position, the firn structure varies at different locations even within the same ice shelf. The upper part of the ice column consists of firn with a density of about $0.35 \mathrm{Mg} \mathrm{m}^{-3}$ at the surface, increasing to $0.82 \mathrm{Mg} \mathrm{m}^{-3}$ at pore close off where the firn turns to solid ice (a depth of about $40 \mathrm{~m}$ ); below, the density increases to $0.915 \mathrm{Mg} \mathrm{m}^{-3}$ at a depth greater than $300 \mathrm{~m}$. Since the density structure, temperature, and ice thickness vary in different places on an ice shelf or tabular iceberg, the average density varies also, affecting the buoyancy of the floating ice mass. For a floating ice mass, the relationship between elevation above sea-water and ice thickness assuming hydrostatic equilibrium is

$$
\bar{\rho}_{\mathrm{i}} H=\rho_{\mathrm{w}}(H-h)
$$

where $\bar{\rho}_{\mathrm{i}}$ and $\rho_{\mathrm{w}}$ are the mean densities of the ice column and sea-water, respectively, $H$ is ice thickness, and $h$ is elevation above sea-level.

Density-depth results were obtained at 18 stations on the Ross Ice Shelf by the seismic short-refraction technique; at four of them densities are also known from ice-core measurements by Gow (1968), Langway (1975), and Chiang and Langway (1978). Average densities were evaluated at each station using the relationship

$$
\bar{\rho}_{\mathrm{i}}=\frac{1}{H} \int_{0}^{H} \rho_{\mathrm{i}}(z) \mathrm{d} z
$$

where $\rho_{\mathrm{i}}(z)$ is the density of ice at depth $z$. Ice thicknesses were measured by radar sounding. Average densities vary as a function of ice thickness, decreasing from about $0.89 \mathrm{Mg} \mathrm{m}^{-3}$ for $H=770 \mathrm{~m}$ to $0.85 \mathrm{Mg} \mathrm{m}^{-3}$ for $H \approx 250 \mathrm{~m}$. To obtain a relationship between $h$ and $H$ for the whole ice shelf, the value of $\bar{\rho}_{\mathrm{i}}$ for each station was used in Equation (1) to calculate $h$, taking $\rho_{\mathrm{w}}=1.0275 \mathrm{Mg} \mathrm{m}^{-3}$. The resulting plot of $h$ against $H$ is shown in Figure 1a. A least-square fit to the data yielded $h=(0.118 \pm 0.005) H+11.6 \pm 1.9$ (solid straight line in Fig. 1a). The corresponding best-fit $H / h$ relationship is $H / h=8.47 H /(H+98.0)$ (solid curved line in Fig. 1a).

To compare the measured results with a generalized model that could be applied to both ice shelves and icebergs, we first assume as a first approximation that the density profile is invariant in space and time. Next, we adjust for the effect of low density by reducing the elevation by a constant amount $d$, where

$$
d=H\left(1-\frac{\bar{\rho}_{\mathrm{i}}}{\rho_{\mathrm{i}}}\right),
$$



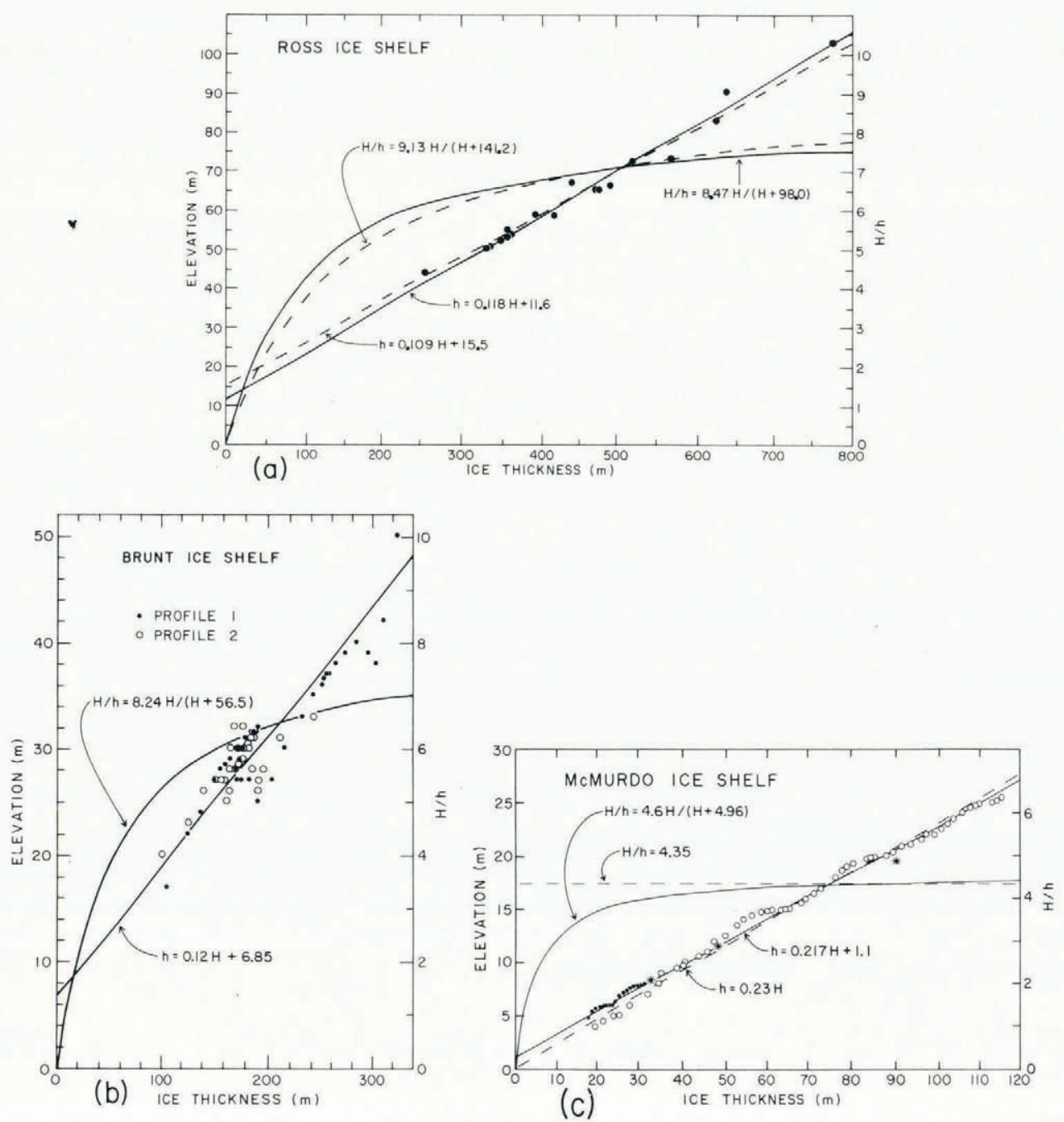

Fig. 1. Surface elevation and ratio of ice thickness to elevation as a function of ice thickness for three ice shelves. Dots and circles show measured values; solid straight lines are least-squares fit to the data; solid curves of $H / h$ are calculated from the straight lines. (a) Ross Ice Shelf; dashed lines refer to the theoretical relation described in the text. (b) Brunt Ice Shelf; data are from Thomas (1973), dots and circles indicate two different profiles. (c) McMurdo Ice Shelf; data are from Kovacs and Gow (1975) (circles), Kovacs and Gow (1977) (dots), and Hochstein and Risk (1967) (asterisk); dashed lines are based on the theoretical model described in the text.

yielding an equivalent solid-ice column. Then, from Equations (1) and (3),

$$
h=\frac{\rho_{\mathrm{w}}-\rho_{\mathrm{i}}}{\rho_{\mathrm{w}}} H+\frac{\rho_{\mathrm{i}}}{\rho_{\mathrm{w}}} d
$$

and

$$
\frac{H}{h}=\frac{\rho_{\mathrm{w}}}{\rho_{\mathrm{w}}-\rho_{\mathrm{i}}} H /\left[H+\frac{\rho_{\mathrm{i}}}{\rho_{\mathrm{w}}-\rho_{\mathrm{i}}} d\right] .
$$


Equation (4a) is a straight line whose slope depends only upon the density of ice and water, and whose intercept is proportional to $d$. The values of $d$ for each station were calculated separately and found to range from $14.4 \mathrm{~m}$ to $24.5 \mathrm{~m}$ with a mean value of $17.4 \mathrm{~m}$, using an ice density of $0.915 \mathrm{Mg} \mathrm{m}^{-3}$. The straight-line relation between $h$ and $H$ and the curve representing the relation between $H / h$ and $H$ using the mean value of $d$ are shown in Figure la (dashed lines: $h=0.109 H+15.5 ; H / h=9.13 H /(H+141.2))$. The slight difference between the measured and calculated lines comes from assuming that $d$ is constant; it is apparent that the difference is not significant, except possibly on very thick ice. Either line can be taken as appropriate for icebergs that calve from the Ross Ice Shelf.

The buoyancy relation for icebergs calved off other ice shelves should be similar to the above, except that different parameters may have to be used. An example is given in Figure Ib, where the ice thicknesses and elevations on two profiles along and across the Brunt Ice Shelf are presented (the values of $H$ and $h$ are obtained from Thomas, 1973). A least-squares fit to the measured values, $h=(0.120 \pm 0.006) H+6.8 \pm 1.5 ; H / h=8.24 H /(H+56.5)$ is shown. The slope of the line is not significantly different from the one obtained for the Ross Ice Shelf. The smaller intercept simply indicates higher average densities in the firn.

The thin McMurdo Ice Shelf exhibits a very different relationship between elevation and ice thickness. Using ice thicknesses obtained from Hochstein and Risk (1967) and Kovacs and Gow $(1975,1977)$, the least-squares fit to the data for $h$ and $H$ was found to be $h=(0.217 \pm 0.002) H+1.1 \pm 0.2$. The slope of this line is higher than the slopes calculated for the Ross and Brunt Ice Shelves by a factor of nearly two, and the intercept is very small, indicating that the ratio of ice thickness to elevation $(H / h)$ is almost constant across this ice shelf. According to the density information given by Hochstein and Risk (1967) and Kovacs and Gow $(1975,1977)$ at a few locations on the McMurdo Ice Shelf, the average density is nearly constant with a mean value of $0.79 \mathrm{Mg} \mathrm{m}^{-3}$. In this case the assumption of a constant firn reduction does not apply. An approximate model using Equation (1), with $\rho_{\mathrm{w}}=1.0275 \mathrm{Mg} \mathrm{m}^{-3}$ and $\bar{\rho}_{\mathrm{i}}=0.79 \mathrm{Mg} \mathrm{m}^{-3}$ then gives $h=0.23 \mathrm{H}$, with a constant $H / h=4.35$ (Fig. 1c). This type of ice shelf and its icebergs have a relatively small elevation above sea-level so that the firn-ice boundary is below sea-level, which makes it possible for liquid brine to penetrate laterally from the sides of the permeable firn region.

If the ice shelf or iceberg includes a saline ice layer, Equation (3) must be replaced by

$$
\bar{\rho}_{\mathrm{i}} H=\rho_{\mathrm{i}}\left(H-d-H_{\mathrm{si}}\right)+\rho_{\mathrm{si}} H_{\mathrm{si}}
$$

where $H_{\mathrm{si}}$ and $\rho_{\mathrm{si}}$ are the thickness and average density of the saline ice respectively. Substituting $\bar{\rho}_{\mathrm{i}}$ from Equation (5) into Equation (1) gives

$$
h=\frac{\rho_{\mathrm{w}}-\rho_{\mathrm{i}}}{\rho_{\mathrm{w}}} H+\frac{\rho_{\mathrm{i}}}{\rho_{\mathrm{w}}} d-\frac{\rho_{\mathrm{si}}-\rho_{\mathrm{i}}}{\rho_{\mathrm{w}}} H_{\mathrm{si}}
$$

and

$$
\frac{H}{h}=\frac{\rho_{\mathrm{w}}}{\rho_{\mathrm{w}}-\rho_{\mathrm{i}}} H /\left[H+\frac{\rho_{\mathrm{i}}}{\rho_{\mathrm{w}}-\rho_{\mathrm{i}}} d-\frac{\rho_{\mathrm{si}}-\rho_{\mathrm{i}}}{\rho_{\mathrm{w}}-\rho_{\mathrm{i}}} H_{\mathrm{si}}\right] .
$$

Equation (6a) shows directly the decrease in elevation that results from the additional loading by the denser saline ice. For example, if the density of the saline ice is $0.927 \mathrm{Mg} \mathrm{m}^{-3}$ (appropriate to a salinity of $4 \%$ at $-3{ }^{\circ} \mathrm{C}$, as reported by Zotikov and others (1980) for the basal zone of the 
Ross Ice Shelf) the decrease in elevation is about 0.12 and $1.2 \mathrm{~m}$ for saline layer thicknesses of 10 and $100 \mathrm{~m}$, respectively. For a relatively high salinity $\left(15 \%\right.$, density $\left.0.953 \mathrm{Mg} \mathrm{m}^{-3}\right)$ the corresponding elevation changes are 0.37 and $3.7 \mathrm{~m}$, respectively.

The relationship shown in Figure 1 does not hold at places affected by intense deformation or by surface or bottom cracks. To demonstrate this we chose an area on the ice shelf (station C16, see Fig. 6) where periodic surface elevation changes were noticeable. Surface elevation and ice thickness along four lines $0.5 \mathrm{~km}$ apart are shown in Figure 2. Elevations were measured by optical leveling relative to a reference point whose absolute elevation $(53.8 \mathrm{~m})$ was calculated from Equation (1) and an average density of 0.874 , which in turn was obtained from seismic short refraction shooting and densities measured on cores from a $100 \mathrm{~m}$ drill hole. Ice thicknesses were measured by continuous radar profiling. The surface elevation variations are about $1 \mathrm{~m}$ in amplitude with an apparent wavelength of $1.5 \mathrm{~km}$. Note that bottom undulations
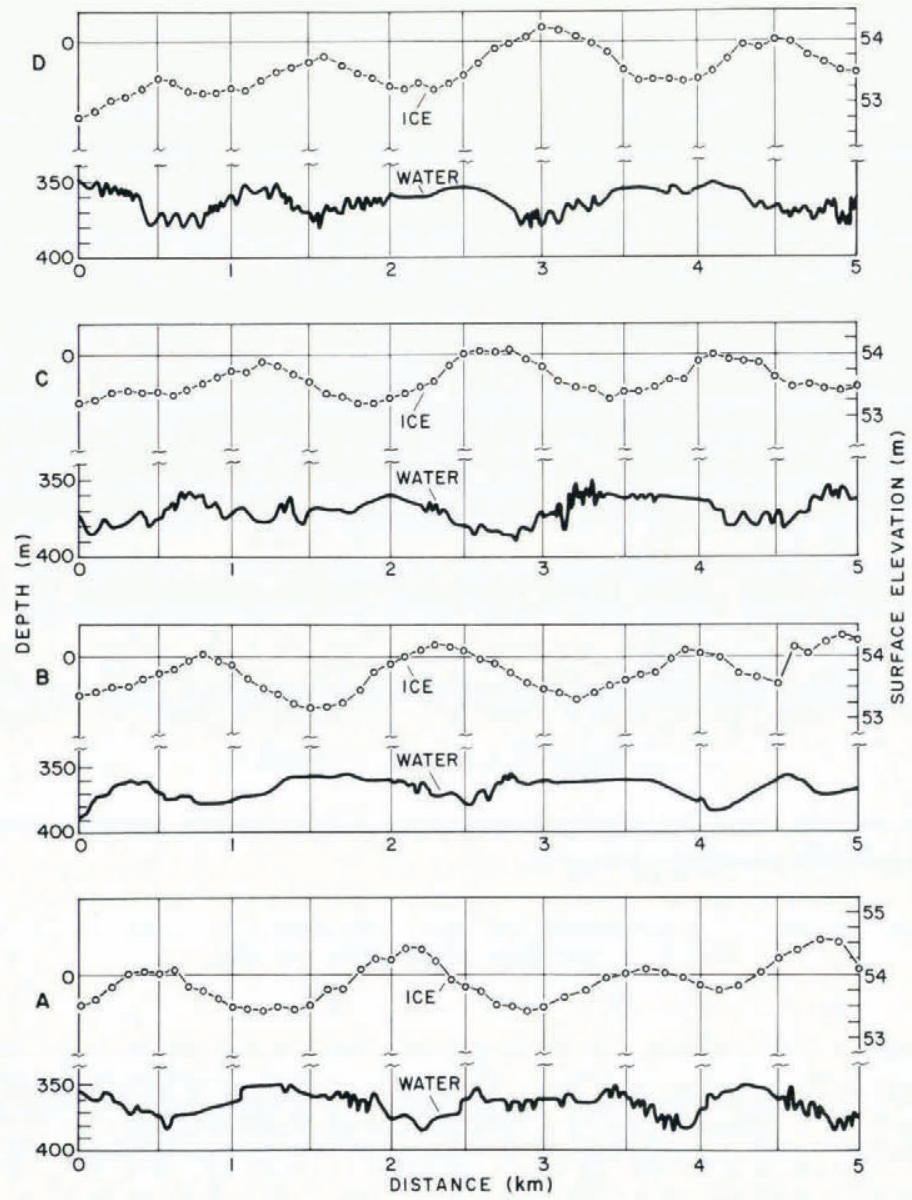

Fig. 2. Surface elevation and ice thickness (depth) along four parallel profiles $0.5 \mathrm{~km}$ apart on the Ross Ice Shelf. Surveyed elevations are given relative to an assumed datum taken to approximate hydrostatic equilibrium. Note 40:1 ratio between depth and elevation scales. 
are only partly correlated with surface elevation changes. Maps of the surface and bottom topography of the area (Fig. 3) show that the actual wavelength of the undulations is about $1.2 \mathrm{~km}$.

Figure 4 shows a profile along a $10.7 \mathrm{~km}$ line chosen to be normal to the ridge-trough trend (see Fig. 3).

From Figure 3 it can be noted that $\mathrm{d} h / \mathrm{d} H \approx 1 / 30$ for the ridge-trough amplitudes. This shows that hydrostatic equilibrium does not hold over one wavelength. On the other hand, a separate linear fit to both surface-elevation and ice-thickness profiles in Figure 4 indicates that over a $10 \mathrm{~km}$ distance $\mathrm{d} h / \mathrm{d} H \approx 1 / 10$, and hydrostatic equilibrium is obtained. It is likely that the very low value of $\mathrm{d} h / \mathrm{d} H$ over one wavelength is due at least in part to mean density variations between the troughs and ridges caused by differential surface accumulation. If the system is actually in hydrostatic balance, then $d$ must be $c .2 \mathrm{~m}$ greater in the troughs than on the ridges; from Equation (3) this corresponds to $c .0 .02 \mathrm{Mg} \mathrm{m}^{-3}$ difference in average density through the top $100 \mathrm{~m}$. Gow and Rowland (1965) show that the accumulation rate on undulations at Byrd Station is $50 \%$ higher in troughs than on ridges. Gow's (1968) comparison of the density-depth structure at different sites on polar ice, along with our observation of density-depth profiles at several sites on the Ross Ice Shelf with different accumulation rates, shows that the different

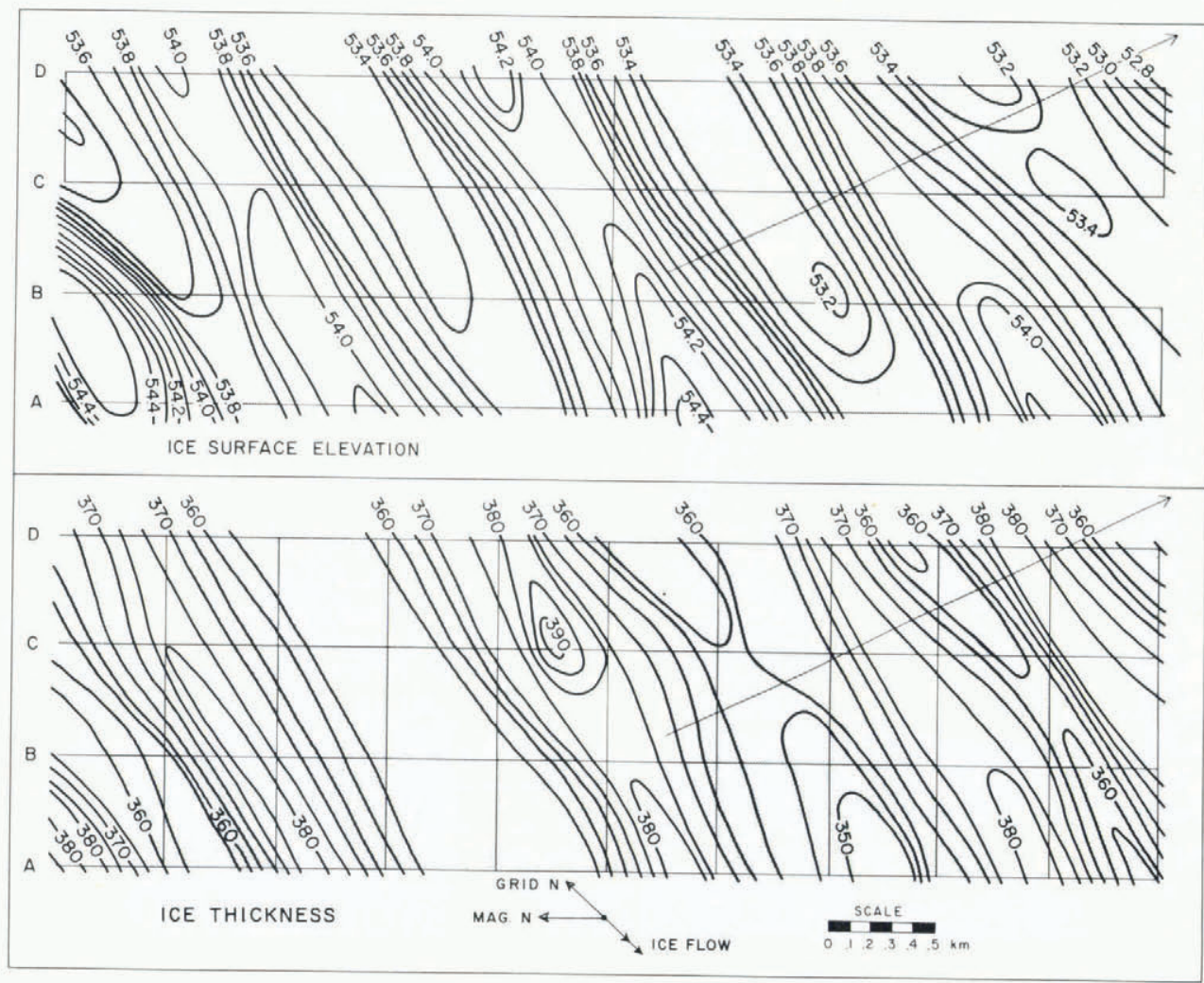

Fig. 3. Maps of surface elevation and ice thickness in the area of the profiles of Figure 2. The thin lines represent survey lines. Contour intervals are $0.1 \mathrm{~m}$ for elevation and $5 \mathrm{~m}$ for ice thickness. Shaded areas show elevations less than $53.8 \mathrm{~m}$ and thicknesses less than $370 \mathrm{~m}$. The long arrow shows the location of the profile of Figure 4 . 


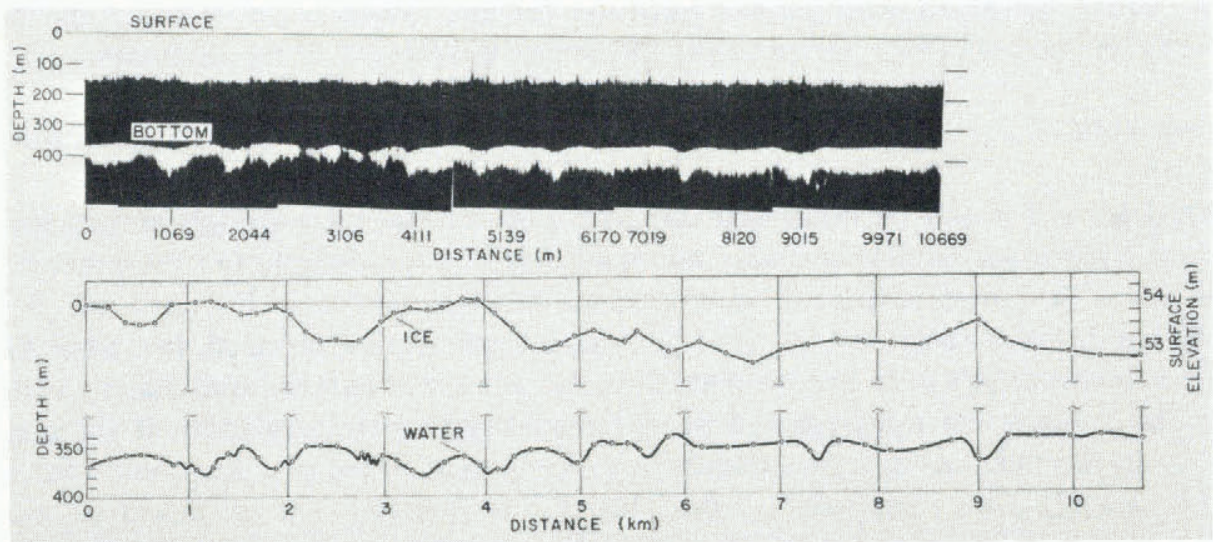

Fig. 4. Profile along a line normal to the trend of the ridge/trough system shown in Figure 3. The photograph at the top is a reproduction of the radar profile. Small circles show observed points of surface elevation and corresponding points on the continuous ice-thickness profile.

accumulation rates could lead to density differences of the required magnitude. It is also possible that the undulations in ice thickness are partially supported by the shear strength of the ice shelf.

These undulations may play an important role in the hydraulics of iceberg towing. The "ripple steepness" (the ratio of ripple amplitude to wavelength) for these ripples is about 0.03 and it may increase during the towing process. According to Tatinclaux and Kennedy ([ $\left.\left.{ }^{c} 1978\right]\right)$, the frictional resistance is $20 \%$ more for a ripple steepness of 0.03 than for a flat interface.

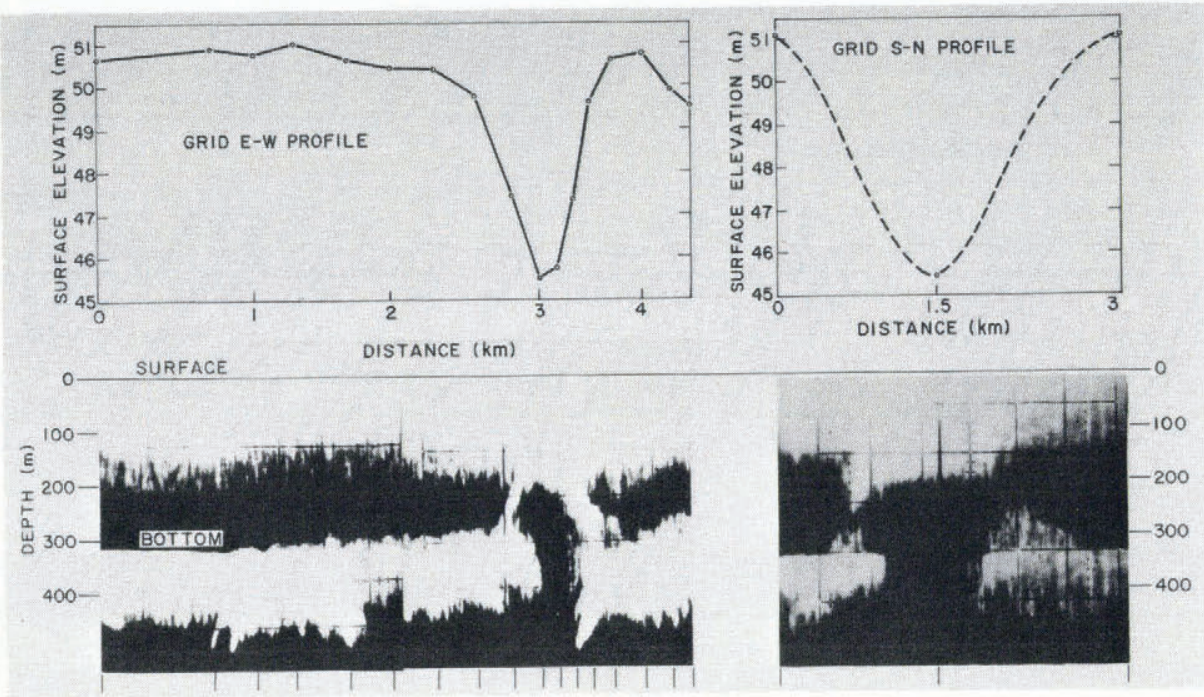

Fig. 5. Surface elevation (upper) and radar (lower) profiles across (left) and along (right) a valley on the Ross Ice Shelf. The profiles intersect at the elevation minimum. The strong hyperbolic reflector in the grid east-west radar profile comes from a reflector at a depth of about $100 \mathrm{~m}$. The distance scale for the east-west profile is slightly non-linear. 
Sometimes a rather large depression (valley) is noticeable on the surface of an ice shelf or tabular iceberg (e.g. Swithinbank, [ ${ }^{\mathrm{c} 1978]}$, fig. 5). The valleys observed by the authors on the Ross Ice Shelf appear to be caused either by buried rifts or by large bottom undulations (Shabtaie and Bentley, 1979[a]). Figure 5 shows the surface-elevation and ice-thickness profiles both across and along such a valley on the Ross Ice Shelf (at Q13, see Fig. 6). The valley is $1.5 \mathrm{~km}$ wide and roughly $3 \mathrm{~km}$ long on the surface, with an elevation drop of about $5.5 \mathrm{~m}$. The hyperbolic echoes in the radar profiles show that a reflector exists at a depth of approximately $100 \mathrm{~m}$ under the surface depression. If the reflector is the apex of a bottom crevasse or rift, as seems probable, it would be interesting to know whether sea-water or saline ice fills the opening.

If the reflector is the bottom of the ice shelf, then $H=100 \mathrm{~m}$ and $h=24$ (using Fig. 1a), which implies a valley depth of about $27 \mathrm{~m}$ compared to a measured elevation difference of $5 \mathrm{~m}$. However, hydrostatic equilibrium could exist if the average width of the bottom rift is only about $5 / 27$ of the valley width, i.e. about $200 \mathrm{~m}$. On the other hand, if we assume the water is frozen inside the rift, then using Equation (6a) and the measured elevation of $46 \mathrm{~m}$, a thickness of about $200 \mathrm{~m}$ of saline ice with a density of $0.943 \mathrm{Mg} \mathrm{m}^{-3}$ (salinity of about $11 \%$ ) is needed to maintain hydrostatic equilibrium. Since an extensive layer of this density and thickness is unlikely, we conclude that unfrozen sea-water penetrates at least part of the bottom rift.

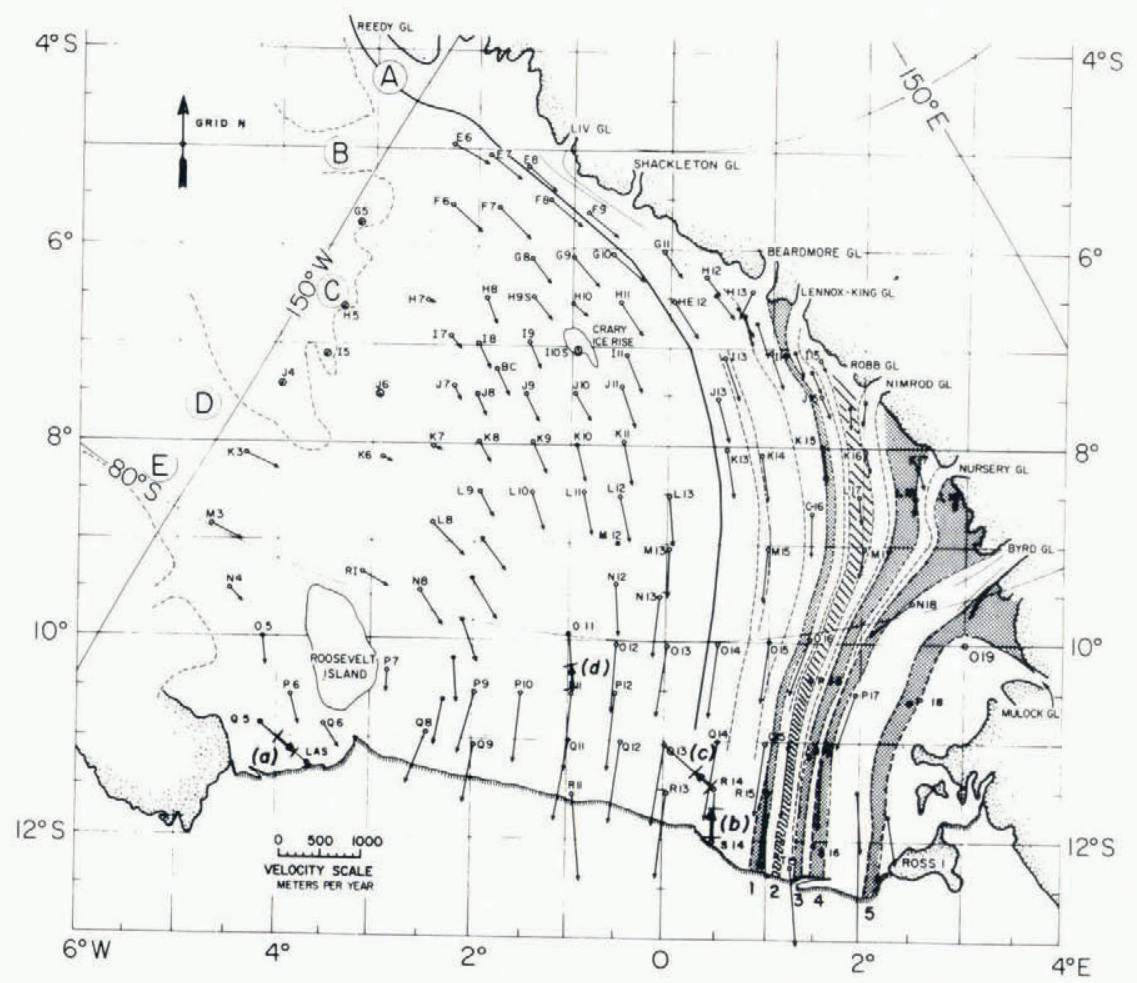

Fig. 6. Map of the Ross Ice Shelf, showing flow vectors (Thomas, 1976 and personal communication, 1980) and flowband boundaries (dashed lines; Bentley and others, 1979). Dotted zones exhibit poor to non-existent radar echoes; the hachured zone exhibits variable reflectivity. The long, heavy line indicates the approximate boundary between East Antarctic and West Antarctic ice. The short heavy arrows marked (a) to (d) refer to radar profiles shown in Figure 8. "F6", “K13", etc. are station identifiers. 


\section{BRINE INFILTRATION}

Brine soaking of ice shelves has been documented by several investigators. The phenomenon is best known on the McMurdo Ice Shelf where Risk and Hochstein (1967) made electrical resistivity profiles which yielded some information about the thickness of the conductive brine layer. They believe that brine soaking is due to horizontal infiltration; the layer of permeable firn below sea-level would allow the brine to move laterally. Brine infiltration by this mechanism would be confined to a layer above the firn-ice boundary. The layer examined by Risk and Hochstein (1967) was nowhere more than $6 \mathrm{~m}$ thick.

Clough (1973) mapped a depth of about $30 \mathrm{~m}$ to the brine later by radar sounding, in agreement with observations he reports from A. J. Heine. Smith and Evans (1972) report that appreciable brine soaking also occurs in the Wordie, Brunt, and Larsen ice shelves. At these locations very shallow echoes, about at sea-level, occasionally appear without any accompanying bottom echo. Swithinbank (1970) has suggested, on the basis of radar profiles in McMurdo Ice Shelf, that some of the shallower reflections coincide with the top of the brine layer. Kovacs and Gow (1975) used an impulse radar to profile both the top and lateral extent of the brine percolation layer in a continuous manner - the identification of the radar reflector as a brine layer was subsequently confirmed by drilling at two separate locations.

Fractures within the ice shelf could afford a path for sea-water to penetrate above the firn-ice boundary and then spread laterally into the firn. Neal (1979), using airborne radio-echo sounding records deduced the existence of such zones in the Ross Ice Shelf. According to him these layers form close to the grounding line between the outlet glaciers along the Transantarctic Mountain front, and can be traced as bands of poor to non-existent bottom reflections almost all the way across the ice shelf. These bands are shown in Figure 6.

A few examples of radar profiles recorded on the surface at stations in each zone are shown in Figure 7. The stations shown in Figure 7b show some features of the down-stream evolution of the radar reflectors. In particular, the depth of the brine layer increases as the ice moves toward the ice-shelf front due to the continuing snow accumulation on the surface. Thus, brine layers formed in that way lie deep within the shelf, in contrast to the case of brine percolation from the sea front, which results in a layer close to sea-level.

Using radar for measuring the thickness of an iceberg and for iceberg selection is strongly recommended. However, care must be taken to identify reflecting boundaries properly. Often, the absorption from the brine layer is so high that there is no bottom echo. For example, the reflecting horizon in Figure 7a, Station K15, appears at a depth of $140 \mathrm{~m}$, but at a neighboring spot a bottom echo was observed and the ice thickness was found to be $380 \mathrm{~m}$, in good agreement with seismic reflection sounding. (For another example, see figure 2 in Kovacs, $\left[{ }^{\mathrm{c}} 1978\right.$ ].) In some places more than one internal reflector is seen (e.g. Figure 7b, Station Q16), suggesting more than one brine layer. Multiple layers could result from reopening of a previously healed fracture, allowing water to penetrate again above the firn-ice boundary. Further measurements are needed to confirm the existence of these brine zones and to study their characteristics, so that their significance to iceberg selection can be determined.

\section{EXISTENCE OF SALINE ICE AT THE BASE}

Several direct and indirect observations have been made to study the possible existence of saline ice at the base of ice shelves. Kovacs and Gow (1977) reported the existence of saline ice 


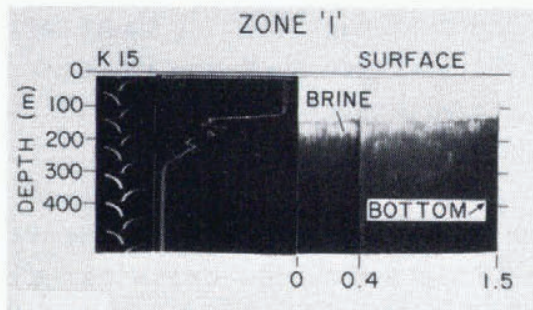

(a)

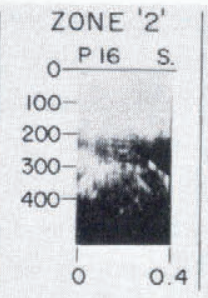

DISTANCE $(\mathrm{km})$
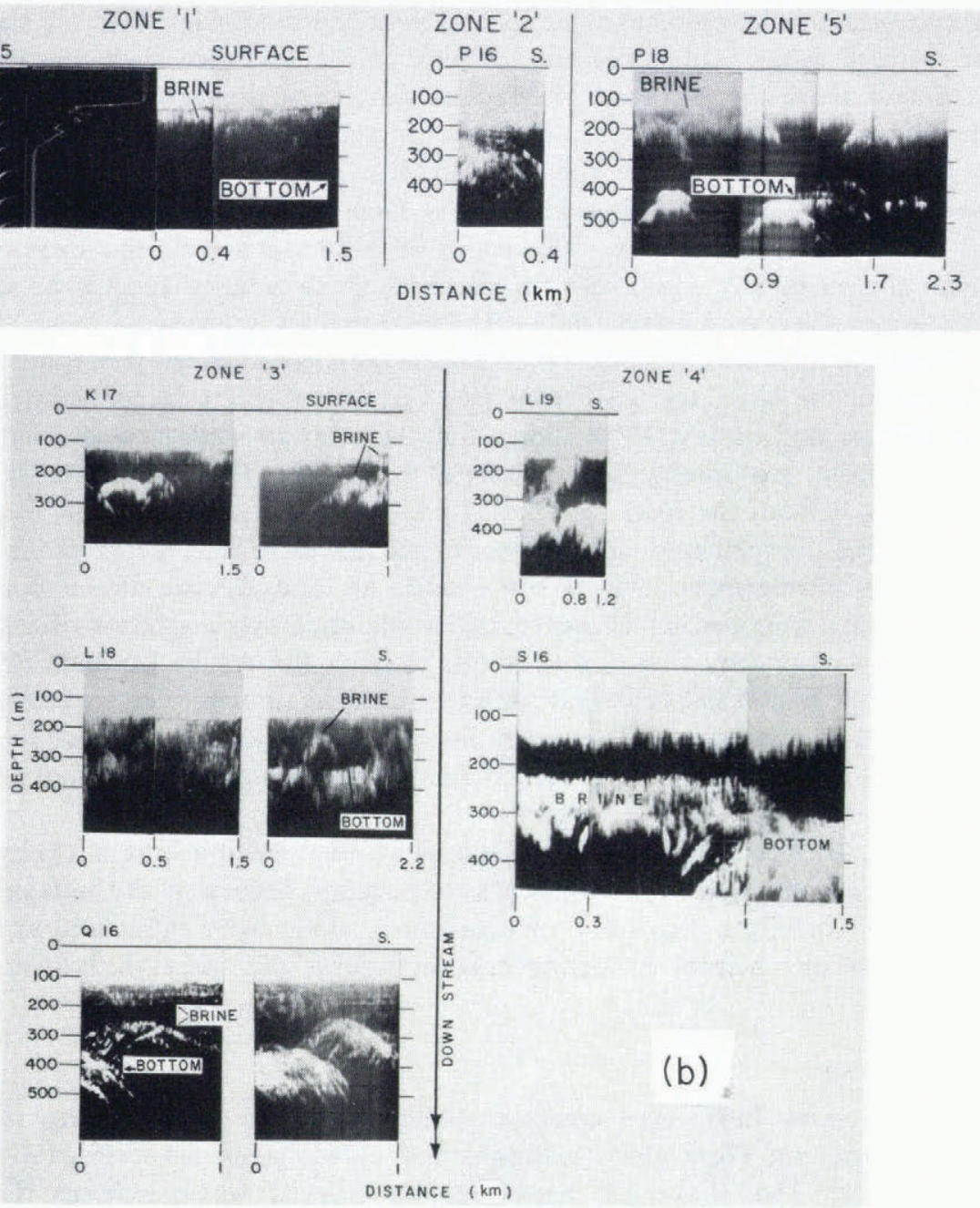

Fig. 7. Radio-echo profiles of brine infiltration zones on the Ross Ice Shelf. (a) (top) Examples of radar profiles recorded on the surface at stations shown (i.e. K15, PI6, etc.); these zones are shown in Figure 6. An example of A display is shown for station $K 15$ at the location where there is no bottom reflection. Each station is located in a different zone (i.e. zone 'l', '2', and '5'). (b) (bottom) Examples of a few stations located in one zone (i.e. stations $\mathrm{K} 17, \mathrm{L18}$, and Q16 in zone '3') down-stream from each other. Stations K17 and Q16 show examples of multilayer brine infiltration.

at the bottom of the Koettlitz Glacier tongue as determined by echo-sounding techniques, and suggested a maximum thickness of $20 \mathrm{~m}$. Recent drilling through the Ross Ice Shelf at the RISP Drill Camp demonstrated that the bottom $6 \mathrm{~m}$ of the ice shelf consists of saline ice. The salinity at the top of the basal layer is $2 \%$, increasing to $4 \%$ at the bottom of the ice shelf (Zotikov and others, 1980). Neal (1979), by measuring the basal radio-echo strengths, made a contour map of radiofrequency dielectric loss, which he interpreted in terms of bottom melting and freezing. Shabtaie and Bentley (1979[b]) demonstrated that radar and d.c. resistivity techniques are useful 
tools for investigating the internal properties and basal characteristics of the ice shelves and thus icebergs. Detailed radar profiling at one location on the Ross Ice Shelf reveals an irregular, patchy reflector above the ice-water interface (Shabtaie and Bentley, 1979[b], fig. 12). This is believed to be an echo from the saline ice boundary just above the ice-water interface. Further evidence from d.c. resistivity studies (Shabtaie and Bentley, 1979[b], fig. 7) and from radar wideangle measurements (authors' unpublished data) support the existence of this saline ice. The average thickness is around $20 \mathrm{~m}$. The radar echo strength from the basal interface was measured at approximately $15 \mathrm{~dB}$ below a calculated value, a fact that could be attributed to an average dielectric absorption layer of $0.75 \mathrm{~dB} / \mathrm{m}$ in $20 \mathrm{~m}$ thick saline ice.

The maximum thickness of $30 \mathrm{~m}$ of the saline ice at some locations is perhaps an upper limit at the bottom of the Ross Ice Shelf front (see Fig. 9b). Other evidence from airborne radar sounding (Bentley and others, 1979) shows that the echo strength increases as the ice moves toward the ice front, presumably from melting at the bottom. The saline ice layer at the bottom of icebergs calving from the Ross Ice Shelf is probably not more than a few meters thick, if it exists at all, since the melt rate increases as the ice moves toward the ice front (Crary, 1961; Thomas, 1973). Furthermore, even if some saline ice does remain at the bottom, it would undoubtedly melt during towing. However, this would obviously not be the case if the saline ice is $150 \mathrm{~m}$ thick, as found by core drilling at one place on the Amery Ice Shelf (Morgan, 1972). Unfortunately, the lateral extent of that saline ice layer has not been determined. Smith (1972) and Swithinbank and others (1977) report radar soundings of an iceberg which they think calved from the Amery Ice Shelf front. They observed an unusually high attenuation of the bottom echo (between 6 and $10 \mathrm{~dB}$ per $100 \mathrm{~m}$ in the ice).

In this case, the icebergs calved from such an ice shelf (with a large thickness of saline ice) would have a relatively high ratio of thickness to elevation because of the high saline ice density at the bottom. Therefore, buoyancy measurements along with radar bottom-echo strength measurements are then helpful in selecting icebergs with no saline ice at the bottom.

\section{BOTTOM CREVASSES}

Bottom crevasses have been detected within many ice shelves using radar sounding techniques (Kovacs and Gow, 1975; Swithinbank, [ ' 1978 ]; Jezek and others, 1979; and authors' unpublished data). They have also been reported to exist within icebergs (Lebedev, 1957; Swithinbank, [ $\left.{ }^{c} 1978\right]$; Kovacs, [ $\left.{ }^{c} 1978\right]$; Weeks and Mellor, [ $\left.\left.{ }^{c} 1978\right]\right)$. The bottom crevasses have a wide variation in distribution, height, and width. Their density of occurrence varies at different locations from a single isolated crevasse to many, spaced regularly. Heights up to $250 \mathrm{~m}$ are found, and bottom widths can exceed $100 \mathrm{~m}$. There is a potential danger related to towing if the crevasses exist in an iceberg, since the stresses associated with sea swell might very well cause an iceberg to break apart along those lines of weakness.

Numerous bottom crevasses are observed in the Ross Ice Shelf. Along the grid eastern margin (Transantarctic Mountains) where the major outlet and alpine glaciers become afloat, radar sounding observations indicate the occurrence of bottom crevasses. In the grid western part, the crevasses are observed along the major ice streams and their constraining walls. Ice rises and islands (grounded ice) within the ice shelves also cause the formation of many bottom crevasses, as exemplified by the grid western part of the Ross Ice Shelf. In some areas the grounded ice (i.e. Roosevelt Island) is not far from the ice front, and the crevasses generated there have a relatively short residence time on the ice shelf. There is then a good possibility that 
they stay at least partially open and trigger calving at the ice-shelf front. If so, the likelihood of having bottom cracks filled with unfrozen sea-water in icebergs is diminished.

Weertman (1980) has shown that bottom crevasses in an ice shelf or tabular iceberg, with a thickness of less than about $400 \mathrm{~m}$, are likely to freeze shut unless there is sufficient sea-water circulation (with temperatures above the melting point) into and out of the crevasse. Jezek (unpublished) has shown that a crevasse probably produces no measurable radar diffraction pattern after freezing, and that, in fact, crevasses generally disappear from the radar record within $100 \mathrm{~km}$ down-stream from their point of formation (i.e. within about 200 years). These observations, along with Weertman's (1980) conclusion, suggest that only crevasses that form not far from the ice-shelf front remain open at the calving margin.

\section{RIFTS AND THEIR ROLE IN TABULAR ICEBERG CALVING}

Rifts are a common feature of Antarctic ice shelves, and they have been observed on several ice shelves (Zumberge and others, 1960; Thomas, 1973). A rift could be either a bottom crack that has opened all the way up to the surface, or a surface crack that has reached to the bottom. Their formation can be due to differential movement of an ice stream and slow-moving or stagnant ice which exists around ice rises and islands within the ice shelves. Some rifts are as much as several hundred kilometers long with a maximum width of a few kilometers.

Rifts are filled with sea-water, and there is evidence that the sea-water is not frozen. In Figure 8 we show several examples of rifts in the Ross Ice Shelf (the location of each example is shown in Fig. 6). The rifts are marked by hyperbolic diffracted echoes off each corner (i.e. the apex and the two bottom corners). The rift in Figure $8 \mathrm{a}$ is $4 \mathrm{~km}$ wide and the surface valley is $45 \mathrm{~m}$ deep. Often, the ice thins towards the rift from both sides (see examples in Fig. 8). This is the same shape as the ice shelf front and is an important factor for iceberg shapes. The thinning presumably is due to some combination of melting at the bottom edges and creep deformation of ice after the rift has formed.

The surface accumulation tends to bury the top of the rifts as they move toward the ice-shelf front forming a shallower valley on the surface (e.g. Figs $9 \mathrm{c}$ and 5). The distribution of the rifts and spacing between them are not well known. Several rifts are observable from the surface and can be seen on the USGS map of the Ross Ice Shelf (U.S.G.S., 1972); many others are buried and are observed by airborne radio echo-sounding. At some locations there appear to be rifts and/or bottom crevasses spaced regularly over many kilometers (see Figs $8 \mathrm{~b}$ and d, and $9 \mathrm{c}$ and $\mathrm{d})$.

The existence of these rifts may be an important factor in the calving of tabular icebergs. This is especially likely in the grid-western part of the Ross Ice Shelf front and on other ice shelves where there is a grounded ice area close to its ice front. It is virtually certain that calving will take place at a site of a large rift, and a single tabular iceberg may be formed. However, as is shown in Figures 8 and 9, several other bottom crevasses and small rifts can exist between the barrier and the large rift so that the large iceberg may rapidly break up into smaller pieces.

\section{STRUCTURE OF ICE-SHELF FRONT}

Radar profiles show the characteristics of the front at a few sites on both the western and eastern parts of the ice shelf. The morphology of the ice shelf in the vicinity of the front is different in different locations. The sounding profiles at four locations are shown in Figure 9. 


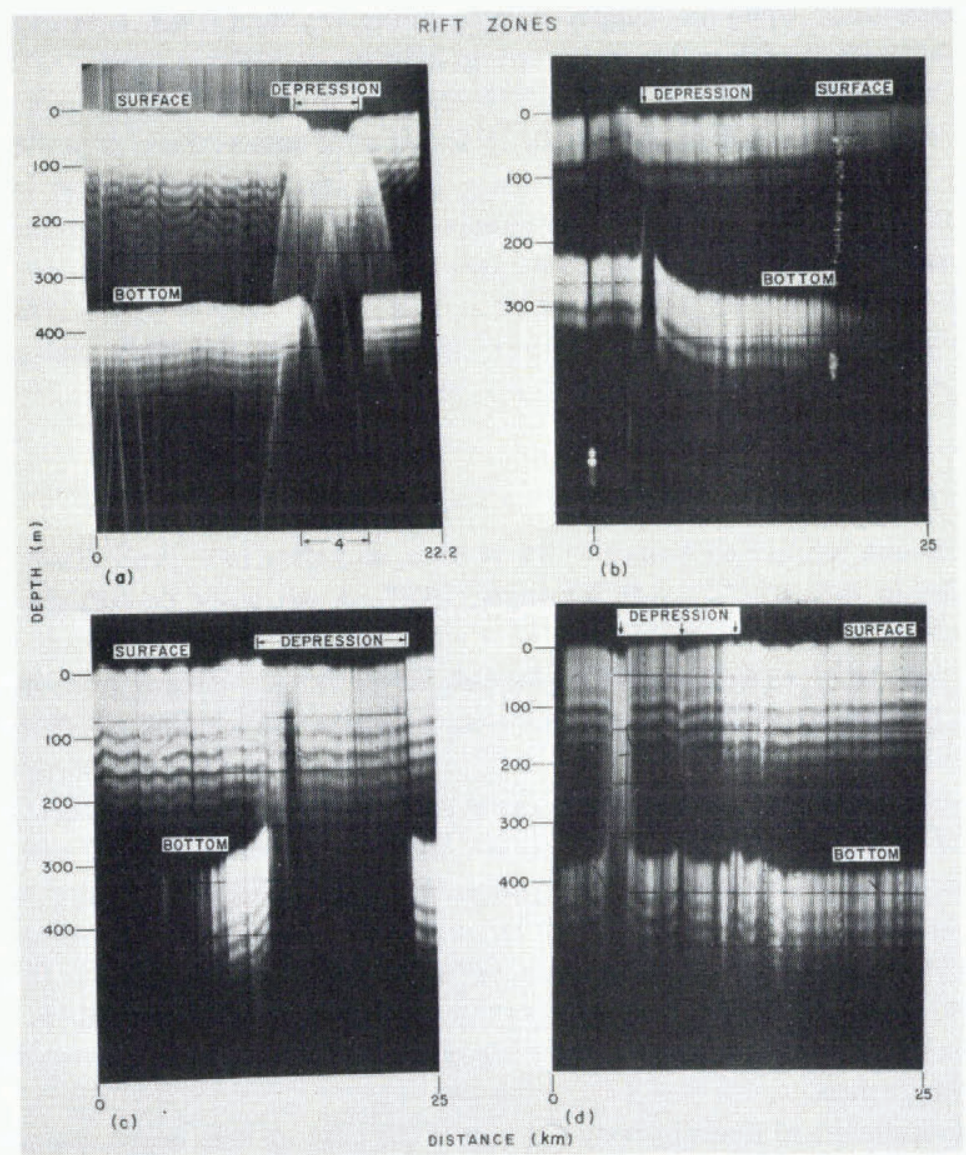

Fig. 8. Airborne radar profiles of rifts in the Ross Ice Shelf at locations indicated in Figure 6. Repeated echoes are from ringing, not internal reflectors. Note that $1 \mathrm{~m}$ of ice on the vertical scale corresponds to $1.7 .3 \mathrm{~m}$ in $\mathrm{the}$ air.

Significant thinning takes place as the ice moves toward the ice-shelf front; thinning at some locations is of the order of $50 \mathrm{~m}$ per $\mathrm{km}$ or more. The western part of the Ross Ice Shelf front is thicker than the eastern part and so will calve thicker, and quite likely larger, icebergs. Figure 9a is a profile of the front along the Byrd Glacier flow band. There is no sign of bottom cracks or rifts since there is no ice rise or island along the flow path. Figure $9 \mathrm{~b}$ shows the structure of the front and the ice up-stream from it in the central part of the ice-shelf front. The ice here passed far up-stream around Crary Ice Rise, where the ice is grounded. There are several small cracks (hyperbolic echoes) at the bottom, two large features that may be buried rifts are also present. There is also another linear reflecting boundary above the ice-water boundary at some locations which we interpret as saline ice (shelf water frozen to the base).

The structure of the front in the grid-western part of the ice shelf is different due to the effect of Roosevelt Island on the flow of ice. Figure 9d shows a profile of the barrier at Little America Station V (station LAS on Fig. 6). There are several rifts or bottom crevasses up-stream from the ice front. The barrier is slightly different in shape than other parts. There is a general thinning 

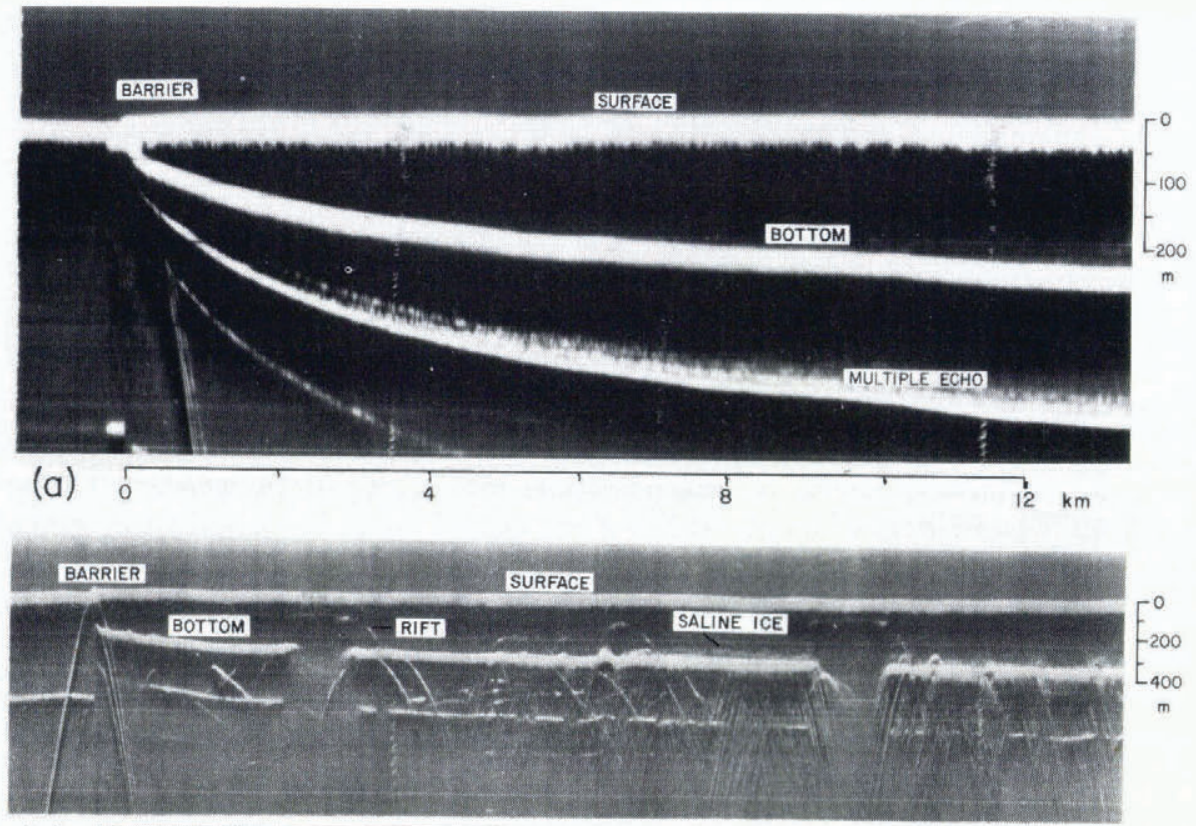

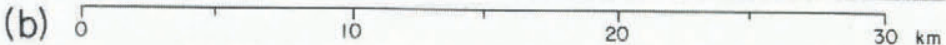

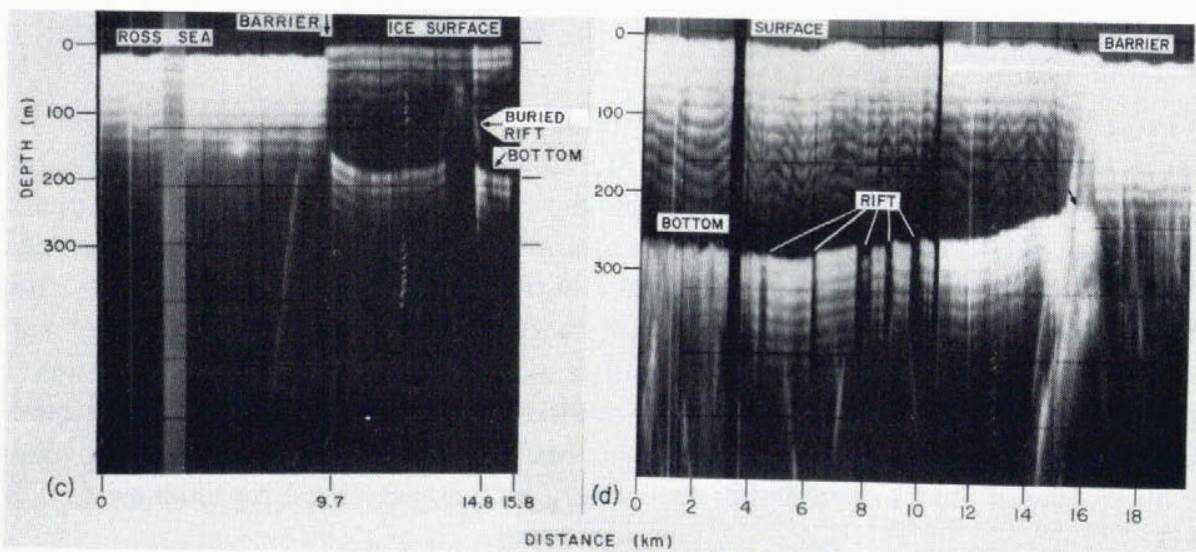

Fig. 9. Airborne radar profiles normal to the Ross Ice Shelf front. (a) Crossing at $13^{\circ} \mathrm{S}$., $1^{\circ} 50^{\prime} \mathrm{E}$. (grid) in flow band from Byrd Glacier. Note absence of bottom cracks. (b) Crossing at $11^{\circ} 45^{\prime} S$., $O^{\circ} 20^{\prime} W$. (grid), showing abundant hyperbolic reflections from bottom and near-bottom irregularities, one or two possible buried rifts, and reflections from presumed saline-ice layers. (c) Crossing at $11^{\circ} 17^{\prime} \mathrm{S}$., $3^{\circ} 20^{\prime} \mathrm{W}$. (grid) showing a distinct buried rift. (d) Crossing at $11^{\circ} 17^{\prime} \mathrm{S} .3^{\circ} 40^{\prime} \mathrm{W}$. (grid) showing several possible buried rifts and one rift, indicated by arrows, reflected in the surface about $1 \mathrm{~km}$ from the barrier. The profiles in (a) and (b) are from the $1974-7.5$ NSF-SPRI-TUD radio-echo sounding flights. Repeated echoes in (c) and (d) are from ringing, not internal echoes.

toward the barrier but starting at about $1 \mathrm{~km}$ from the ice front the ice appears to get thicker. Neither the cause of this feature, nor whether it is representative, is known. 
The profile of the front $20 \mathrm{~km}$ grid east of LAS is shown in Figure 9c. The boundaries of what will probably be an iceberg in the near future are marked by the front and the buried rift $4 \mathrm{~km}$ in from the edge. Due to differential thinning at each side, the surface elevation of the "near-future iceberg" is maximum at the center, corresponding to thicker ice at the center than at the sides.

Where calving takes place by rifting, an approximate time of calving can be estimated; we use the $4 \mathrm{~km}$ ice section of Figure $9 \mathrm{c}$ as an example. We further assume that the ice shelf near the present front had a thickness profile similar to that at the rift when the previous iceberg broke off. On those assumptions, the change in the profile is caused by differential melting at the bottom and thinning by extension flow. The comparison of ice thickness of profiles at the present front and the neighboring rift shows that the ice has thinned about $25 \mathrm{~m}$ at the front and $10 \mathrm{~m}$ at $1 \mathrm{~km}$ up-stream. Using an accumulation rate of $0.3 \mathrm{~m}$ of ice/year (Clausen and Dansgaard, 1977), a vertical strain of $-0.5 \mathrm{~m}$ of ice/year (Crary, 1961), and a melt rate of $0.8 \mathrm{~m}$ of ice/year (measured at LAS V, Crary, 1961), the amount of thinning due to melting and creep deformation is roughly $1 \mathrm{~m} /$ year a few kilometers away from the ice front. This implies that the $10 \mathrm{~m}$ thinning $1 \mathrm{~km}$ from the front must have taken place in a time span of approximately 10 years. Since the ice velocity at this site is $0.5 \mathrm{~km} /$ year (Thomas, 1976) and the distance between the seaward facing walls is $5 \mathrm{~km}$, this implies that the present ice-shelf front was formed near the present location of the buried rift.

INVESTIGATION OF THE MASS-BALANCE RATE AND TEMPERATURE VARIATIONS BY ELECTRICAL RESISTIVITY SOUNDING

The mass balance of an iceberg can be estimated by applying techniques similar to those described in Bentley (1977) and Shabtaie and Bentley (1979[b]), with some modifications. The electrical resistivity sounding method was employed to estimate the bottom mass-balance rates of the Ross Ice Shelf, through the effect of melting at the bottom on the temperature-depth gradient. On an ice shelf, the density and temperature, and thus the resistivity, vary only with depth, but for icebergs that can no longer be assumed, since the temperature will also vary with distance from the sides. The initial temperature condition for the ice column will be the temperature-depth profile of the ice shelf near the ice front. Then, if a satisfactory model of the temperature boundary conditions can be found, resistivities can be calculated and compared against the measured values obtained at the iceberg site, as described by Shabtaie and Bentley (1979[b]).

\section{ACKNOWLEDGMENTS}

We are especially grateful to D. R. MacAyeal for providing unpublished results of surface elevation from two profiles on Q13 and C16 base camps. Other individuals who assisted in the field work in various ways were L. L. Greischar, D. G. Albert, E. Penn, D. Hall, and J. W. Clough.

Field work and data analysis were supported by National Science Foundation grants DPP76-01415 and DPP79-20736.

MS. received 29 June 1981 


\section{REFERENCES}

Bentley, C. R. 1977. Electrical resistivity measurements on the Ross Ice Shelf. Journal of Glaciology, Vol. 18, No. 78, p. 15-35.

Bentley, C. R., and others. 1979. Ice-thickness patterns and the dynamics of the Ross Ice Shelf, Antarctica, by C. R. Bentley, J. W. Clough, K. C. Jezek, and S. Shabtaie. Journal of Glaciology, Vol. 24, No. 90, p. $287-94$.

Chiang, E., and Langway, C. C., jr. 1978. Antarctic ice core recovery. Antarctic Journal of the United States, Vol. 13, No. 4, p. 59-61.

Clausen, H. B., and Dansgaard, W. 1977. Less surface accumulation on the Ross Ice Shelf than hitherto assumed. [Union Géodésique et Géophysique Internationale. Association Internationale des Sciences Hydrologiques. Commission des Neiges et Glaces.] Symposium. Isotopes et impuretes dans les neiges et glaces. Actes du colloque de Grenoble, août/septembre 1975, p. 172-76. (IAHS-AISH Publication No. 118.)

Clough, J. W. 1973. Radio echo sounding: brine percolation layer. Journal of Glaciology, Vol. 12, No. 64, p. $141-43$.

Crary, A. P. 1961. Glaciological studies at Little America Station, Antarctica, 1957 and 1958. IGY Glaciological Report Series (New York), No. 5.

Gow, A. J. 1968. Deep core studies of the accumulation and densification of snow at Byrd Station and Little America V, Antarctica. U.S. Cold Regions Research and Engineering Laboratory. Research Report 197.

Gow, A. J., and Rowland, R. 1965. On the relationship of snow accumulation to surface topography at "Byrd Station", Antarctica. Journal of Glaciology, Vol. 5, No. 42, p. 843-47.

Hochstein, M. P., and Risk, G. F. 1967. Geophysical measurements on the McMurdo Ice Shelf, Antarctica, during 1965-1966. New Zealand. Dept. of Scientific and Industrial Research. Geophysics Division, Report No. 47.

Jezek, K. C. Unpublished. Radar investigations of the Ross Ice Shelf, Antarctica. [Ph.D. thesis, University of Wisconsin-Madison, 1980.]

Jezek, K. C., and others. 1979. Electromagnetic sounding of bottom crevasses on the Ross Ice Shelf, Antarctica, by K. C. Jezek, C. R. Bentley, and J. W. Clough. Journal of Glaciology, Vol. 24, No. 90, p. 321-30.

Kovacs, A. [ ${ }^{\mathrm{c}} 1978$.] Iceberg thickness and crack detection. (In Husseiny, A. A., ed. Iceberg utilization. Proceedings of the first International Conference and Workshops on Iceberg Utilization for Fresh Water Production, Weather Modification, and Other Applications held at Iowa State University, Ames, Iowa, USA, October 2-6, 1977. New York, etc., Pergamon Press, p. 131-45.)

Kovacs, A., and Gow, A. J. 1975. Brine infiltration in the McMurdo Ice Shelf, McMurdo Sound, Antarctica. Journal of Geophysical Research, Vol. 80, No. 15, p. 1957-61.

Kovacs. A., and Gow, A. J. 1977. Subsurface measurements of the Ross Ice Shelf, McMurdo Sound, Antarctica. Antarctic Journal of the United States, Vol. 12, No. 4, p. 146-48.

Langway, C. C., jr. 1975. Antarctic ice core studies. Antarctic Journal of the United States, Vol. 10, No. 4, p. 152-53.

Lebedev, V. L. 1957. Antarktika. Moscow, Gosudarstvennoye Izdatel'stvo Geograficheskoy Literatury. [English translation: Antarctica. Moscow, Foreign Languages Publishing House, 1959.]

Morgan, V. I. 1972. Oxygen isotope evidence for bottom freezing on the Amery Ice Shelf. Nature, Vol. 238, No. 5364, p. 393-94.

Neal, C. S. 1979. The dynamics of the Ross Ice Shelf revealed by radio echo-sounding. Journal of Glaciology, Vol. 24, No. 90, p. 295-307.

Risk, G. F., and Hochstein, M. P. 1967. Subsurface measurements on the McMurdo Ice Shelf, Antarctica. New Zealand Journal of Geology and Geophysics, Vol. 10, No. 2, p. 484-97.

Shabtaie, S., and Bentley, C. R. 1979[a]. Evidence for ocean currents beneath the Ross Ice Shelf from radar and electrical resistivity sounding. Eos. Transactions, American Geophysical Union, Vol. 61, No. 5, p. 49. [Abstract.]

Shabtaie, S., and Bentley, C. R. 1979[b]. Investigation of bottom mass-balance rates by electrical resistivity soundings on the Ross Ice Shelf, Antarctica. Journal of Glaciology, Vol. 24, No. 90, p. 331-43.

Smith, B. M. E. 1972. Airborne radio echo sounding of glaciers in the Antarctic Peninsula. British Antarctic Survey. Scientific Reports, No. 72.

Smith, B. M. E., and Evans, S. 1972. Radio echo sounding: absorption and scattering by water inclusion and ice lenses. Journal of Glaciology, Vol. 11, No. 61, p. 133-46.

Swithinbank, C. W. M. 1970. Ice movement in the McMurdo Sound area of Antarctica. [Union Géodésique et Géophysique Internationale. Association Internationale d'Hydrologie Scientifique.] [International Council of Scientific Unions. Scientific Committee on Antarctic Research. International Association of Scientific Hydrology. Commision of Snow and Ice.] International Symposium on Antarctic Glaciological Exploration (ISAGE), 
Hanover, New Hampshire, U.S.A., 3-7 September 1968, p. 472-87. I(Publication No. 86 |de l'Association Internationale d'Hydrologie Scientifique].)]

Swithinbank, C. W. M. [ ${ }^{\mathrm{c}}$ 1978.] Remote sensing of iceberg thickness. (In Husseiny, A. A., ed. Iceberg utilization. Proceedings of the first International Conference and Workshops on Iceberg Utilization for Fresh Water Production, Weather Modification, and Other Applications held at Iowa State University, Ames, Iowa, USA, October 2-6, 1977. New York, etc., Pergamon Press, p. 100-07.)

Swithinbank, C. W. M., and others. 1977. Drift tracks of Antarctic icebergs, by C. [W. M.| Swithinbank, P. McClain, and P. Little. Polar Record, Vol. 18, No. 116, p. 495-501.

Tatinclaux, J.-C., and Kennedy, J. F. [ ${ }^{\mathrm{C}}$ 1978.] Ripple formation at ice-flow interfaces: potential effects on iceberg transport. (In Husseiny, A. A., ed. Iceberg utilization. Proceedings of the first International Conference and Workshops on Iceberg Utilization for Fresh Water Production, Weather Modification, and Other Applications held at Iowa State University, Ames, Iowa, USA, October 2-6, 1977. New York, etc., Pergamon Press, p. 276-82.)

Thomas, R. H. 1973. The dynamics of the Brunt Ice Shelf, Coats Land, Antarctica. British Antarctic Survey. Scientific Reports, No. 79.

Thomas, R. H. 1976. Ice velocities on the Ross Ice Shelf. Antarctic Journal of the United States, Vol. 11, No. 4. p. $279-81$.

U.S.G.S. 1972. Ross Ice Shelf. Washington, D. C., U.S. Geological Survey. [Map, scale 1:2 188 800.]

Weeks, W. F., and Mellor, M. [ ${ }^{\mathrm{c}}$ 1978.] Some elements of iceberg technology. (In Husseiny, A. A., ed. Iceberg utilization. Proceedings of the first International Conference and Workshops on Iceberg Utilization for Fresh Water Production, Weather Modification, and Other Applications held at Iowa State University, Ames, Iowa, USA, October 2-6, 1977. New York, etc., Pergamon Press, p. 45-98.)

Weertman, J. 1980. Bottom crevasses. Journal of Glaciology, Vol. 25, No. 91, p. 185-88.

Zotikov, I. A., and others. 1980. Core drilling through the Ross Ice Shelf (Antarctica) confirmed basal freezing, by I. A. Zotikov, V. S. Zagorodnov, and Ju. V. Raikovsky [i.e. Yu. V. Raykovskiy]. Science, Vol. 207, No. 4438, p. $1463-65$.

Zumberge, J. H., and others. 1960. Deformation of the Ross Ice Shelf near the Bay of Whales, Antarctica, by J. H. Zumberge, M. Giovinetto, R. Kehle, and J. Reid. I.G.Y. Glaciological Report Series (New York), No. 3. 